\title{
Principle of Most Favoured Nation: Description, Modern Evolution, and Analysis of the Exceptionality of the Principle in A Contemporary World
}

\author{
Frans Lavdari
}

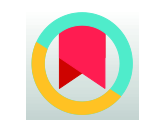

Department of Business and Management, LUISS Guido Carli University

Corresponding author email: frans.lavdari@outlook.com

Received: 13 September 2021 / Revised: 23 September 2021 / Accepted: 23 November 2021 / Published: 05 December 2021

\begin{abstract}
The "most favoured nation" principle is the cornerstone of the modern international trading system. Each state is obliged to reflect the benefits it offers a nation over other WTO adherents as well. This system, however, although it proved effective until the last century for the creation of an international free trade system, today has lost its capabilities, mainly degraded by "private" international agreements between nations, such as RTA, FTA, PTA and REIO, who have torn apart the principle and created groups of nations, each with their own personal advantages which are bestowed only on the nations adhering to the agreement. The following sections aim to give a description of this phenomenon and its evolutions up to modern times, through an analysis of the various exceptionality of the "most favored nation" principle, of the situation of modern free trade agreements, and of the effects both for national legislations and markets, in order to be able to understand what are the conditions facing the global market today and, above all, if the principle of "non-discrimination" is still a cornerstone in the trade relations in the MFN.
\end{abstract}

Keywords: GATT, WTO, MFN.

\section{Introduction}

As established in the document signed by the United Nations Conference on Trade and Development on February 29, 1964, the General Agreement on Tariffs and Trade (GATT), born in 1947, has the task of "raising the standard of living, guaranteeing full employment and a large and steadily growing volume of real income and effective demand, developing the full use of the world's resources and expanding the production and exchange of goods and promoting the progressive development of the economies of all contracting parties" (GATT, 1964). The GATT would therefore have the task of regulating relations between contractors in relation to commercial needs, to then be placed as a "cornerstone" within which an International Trade Organization [ITO] would subsequently have to be born, in order to coordinate, thereafter, in an equitable manner and under a single legislation, subsequent trade agreements (Rubin, 1981; Ojha, 2020).

The work of the United Nations Conference on Trade and Employment, which lasted from November 1947 to March 1948, ended with a document, "the Final Act of the United Nations Conference on Trade and Employment" (UNCTAD, 1948; Giannelli, Paglialunga \& Turato, 2021) which established a series of considerations, such as the institution of a single currency, the Bancor, with the task of facilitating the development of even the most backward economies (Kregel, 2021, p.7). The proposal ran aground due to conflicts of interest, primarily the United States which was among the first supporters of the project, due to multiple differences in the regulation of foreign investments, patriotic concerns of possible supranational influences on the domestic economies of the states, as well as for "an inadequate exercise of political entrepreneurship" (Berger, Fengler, Owetschkin \& Sittmann, 2021, pp.136-137; Borrows \& Schwartz, 
2020). If ITO had become operational, the transformations of the world economies that influenced the operational performance of the GATT could have been managed in a different way.

On the GATT, it is undeniable the consideration that the principle of most favoured nation treatment (hereinafter MFN) plays a central role, also given by its position within the agreement (Article I). MFN is an expression of the free market. The purpose of this principle is to impose equal treatment between all the parties to an agreement, or to recognize the same facilities also for those third countries that enter into agreements with the first two. The increase or decrease in tariffs must, therefore, be equal and not harm some contractors in favour of others, due to the non-discriminatory component that is pursued by the GATT (Cottier, Mavroidis \& Blatter, 2000). However, this definition already meets a first criticism from the World Trade Organization (hereinafter WTO) which has established how in reality the nondiscriminatory component should be applied equally among all members of the organization, on the basis of a principle of "universality" of the MFN and therefore not only to those with whom you are contracting an agreement at that time or related third states in relation to the contracting parties. This criticism, in theory, should not exist, as the MFN is a universal principle, that is, the contracting nations to the WTO agreement must mandatorily apply the advantages they confer on another party to all other parties to the organization. But this is not always the case. First, it is necessary to consider how this principle is interpreted. The application of the principle can have a double interpretation, such as "conditional" or "unconditional". We speak of unconditional MFN when the application of the most favoured principle is automatically granted to a third country that complies with certain requirements (first of all, accession to WTO). On the contrary, we speak of "conditional" when instead the application is underlying the signing of certain reciprocity requirements, which can be either of a commercial nature (reduction of equal taxation between the contracting parties) or of a fiscal nature (payment for the granting of the title) (Arndt, 1986). The nature of the MFN therefore varies on the basis of the relationships that exist between the states within an agreement, and on what they can offer to the other party. In other words, it is based on the relationship of "reciprocity".

The "rock on which the system was founded" of GATT, however, has shown its fragility over the years. Over time, nations have pursued practices to create more favourable connections with specific trading partners. Thus, were born the "exceptions" in trade agreements in which the unconditional MFN lost its universality, including "regional trade agreements [" RTA "], preferential trade agreements [" PTA "]" and "free trade agreements [ "FTA"]". Still, other peculiarities have been made to the OMC system, such as the Generalized System of Preferences ["GSP"]. These specificities have been recognized as an integral part of the WTO system with the aim of encouraging the development of third world countries, as indicated in the Fourth Ministerial Conference of the World Trade Organization in Doha, Qatar, in November 2001. It is clear, therefore, the presence of a widespread practice of erosion of the MFN system by WTO member nations. Although some multilateral trade negotiations (MTNs) such as the 1973-79 Tokyo Round have tried to recognize the reliability and stability of the GATT system, it is undeniable that the behaviour of nations is eroding its foundations, resulting in a "Departure from many of these principles. The first of the compromised principles is that of general acceptance of most favoured nation treatment."

\section{History and Definition of MFN}

\subsection{Brief Historical Note}

The application of the most favoured nation principle dates back to the 11th century (ILC, 1975), and further evidence has been found in subsequent treaties, such as the Treaty of Madrid of 1667 or the Treaty of Jay of 1794, although its application in a modern key is could be found in the "first modern commercial treaty" in contemporary history (Harstad, 2021, p.5; Grossman, 2016; Goyal, 2021), the Cobden-Chevalier Treaty of 23 January 1860 signed between France and the United Kingdom on the reduction of customs tariffs. 
Frans Lavdari, Extsv. Rev.; Vol. 1, Issue 1, pp: 16-29, 2021

Over the past three centuries, the MFN has undergone a rather particular evolution. Until the birth of the first sprouts of industrialization in the $1700 \mathrm{~s}$, the world used a system of "conditional" MFN agreements, and therefore relegated to the obligation of reciprocity with the counterpart. This is also the result of the first international agreement signed by the United States as an independent nation in 1778, the " Treaty of Amity and Commerce" signed with France (Choukroune \& Nedumpara, 2021, p.477), in which the United States agreed to recognize the first to have the right to treatment as a favoured nation by expressing the willingness to receive fair compensation for the treatment conferred: "there should be no discrimination in French ports against US products as in contrast with other countries" (Chester Lloyd, 1908). At that juncture, the application of a conditional MFN proved to be the right choice for a nation, the United States, heavily backward on an industrial level and dependent on exports from the old continent. The use of conditionality, however, did not last long, as its application in trade agreements was interrupted with a stance by the great powers.

Before the second half of the nineteenth century, Britain entered into "unconditional" agreements with third states because of the liberal ideas that flowed into public opinion. However, upon discovering that the agreements concluded with France (defined by the emperor Louis Napoleon as people capable of making "revolutions, not reforms") (Morley, 1905, p.711), which instead applied a conditional MFN, were more favourable to the counterpart, Great Britain decided to impose the "unconditional" character of the MFN in subsequent agreements (Sharmin, 2020; Conroy, 1927). Since then, the application of the unconditional MFN has remained an increasingly common practice in trade relations between states, and the United States pioneered its success. After becoming an economic and industrial superpower, they decided to abandon the conditional character of the MFN in the agreements in favour of the unconditional one, also resulting from the adoption of targeted national policies, such as the RTAA of 1934. Having been among the leaders in the construction of the GATT, the United States undertook to introduce the "unconditional" meaning in the MFN, transforming it into Article I of the GATT. The decision to prevent the use of a conditional MFN originated in the first half of the twentieth century, when, in the midst of the crisis that resulted in the Great Depression of the 1930s, Herbert Hoover's Republican-chaired Congress signed the introduction of the Smoot - Hawley Tariff Act on June 17, 1930, which increased customs tariffs for 20,000 products, reaching peaks like that of the same year of 61\% (Taussig, 1889). This protectionism was linked to the need to protect domestic manufacturing and agricultural products from foreign ones, especially those of third world countries, which would have torn the already shaky economy. The result was an international response of the same proportions, with the consequent collapse of exports by $67 \%$ (Ojha, 2020). Meanwhile, the European nations that had trade agreements with the United States, such as the United Kingdom, shifted their interest mainly towards the colonies, giving way to greater privileges for these areas of the world that could use this system of "imperial preference" to create conditional MFN agreements in their favour (Palen, 2021; Labinski, 2017).

The growth of this preferential treatment prompted the subsequent Democratic government of Roosevelt to issue the RTAA ("Reciprocal Tariff Act") which gave the power to the President to be able to reduce customs taxes up to $50 \%$ if the commercial partner had also done the same. The attempt to return to a commercial policy with an unconditional MFN was not, however, easy (Claussen, 2021; Tasca, 1938, p.39). For Tasca, factors such as the analyses of national administrations to establish the decrease in prices (which was somewhat slow and bureaucratic) and fears of sudden change had slowed the return to the unconditional MFN system (p.97). The GAT'T of 1947 was born precisely for this reason: to be able to create a universal principle in the commercial field with unconditional reciprocity relations, which prevented the creation of possible preferential corridors of some nations, in particular those in the developing world (Rubin, 1981, 223). The GATT was finally absorbed in 1995 by the establishment of the World Trade Organization (hereinafter "WTO"), as well as its functions. The rules established in the GATT of 1947 remained substantially unchanged, such as, in fact, the principle of the most favoured nation in its interpretation of "unconditional", even if variations and exceptions to the rule became more and more frequent, crumbling its real functions, as will be shown from the following pages. 


\subsection{MFN - Definition and Purpose}

Taking into consideration article I: 1 of the 1994 GATT, it is found that the most favoured nation principle is a mandatory general principle of non-discrimination of products marketed by other WTO member nations: "the obligation to treat the nation most favoured, widely known as MFN treatment obligation, requires WTO members not to discriminate between products originating in or destined for different countries.

According to this: "any advantage, favour, privilege, or immunity granted by any [member] to any product originating in or destined for any other country is granted immediately and without conditions to the like product originating in or destined for the territories of all other [members]. " This advantage covers "customs duties and charges of any kind imposed or related to import or export or imposed on the international transfer of payments for imports or exports" as well as the "method of collection of such duties and charges. "When a nation confers a privilege on a counterparty to the WTO, whether this is a tax or commercial advantage, the same advantage must be compulsorily applied to all other nations adhering to the organization (GATT, 1994). The conditions on the basis of which the following principle applies were expressed by the Appellate Body (AB) in the Canada and EU question (EC - Seal Products, 2009), stating that: (i) the product traded must be "similar" to that of the other WTO country; (ii) the product acquires an "advantage, favour, privilege or immunity" from the trade established; (iii) such product privileges are granted "immediately and unconditionally" between WTO member nations (Siswanto, 2021, p.30; Vadi, 2014).

The purpose of the MFN, therefore, is to make it possible to market and sell similar products between nations adhering to the equal WTO both from a legal (de-iure) and practical (de-facto) point of view, as recalled by the General Agreement on Trade in Services [hereinafter, "GATS"] in the EC - Bananas III issue (Choukroune \& Nedumpara, 2021, p.341).

\section{Characteristics of the MFN: Legislative Interference and Exceptions from the Doha Round}

\subsection{Reciprocity}

It is good to remember, first of all, what kind of "reciprocity" we are talking about. As Cebi \& Ludema (2002, pp.1-6) recall, there are two forms of reciprocity. In the first case, the reciprocal relationship occurs when, to the voluntary action of a subject, one responds with a "contingent" action of equal intensity (for example, if you bring a gift to a friend's birthday, the friend will one in turn). On the other hand, by "mutual relation" is meant when a behaviour of "own free will" is carried out, from which an obligatory and same response is not expected. The GATT, through article I, adheres to the first theory, that is to say something is offered (for example, reduction of customs tariffs) to receive an economic or commercial offer of equal intensity that will have equal value towards all the national realities adhering to the WTO. Taking into consideration the case of "Belgian family allowances", the 1952 panel report contains the following results: "According to the provisions of paragraph 1 of Article I of the General Agreement, any advantage, favour, privilege or immunity granted by Belgium to any product originating in the territory of any country with respect to all matters referred to in paragraph 2 of Article III is granted immediately and unconditionally to the like product originating in the territories of all contracting parties. Belgium has granted the exemption from the present levy to products purchased from public bodies when they originate in Luxembourg and the Netherlands, as well as in France, Italy, Sweden and the United Kingdom. ... It is clear that this exemption should be granted unconditionally to all other contracting parties.

The consistency or otherwise of the family allowance scheme in force in the territory of a given contracting party with the requirements of the Belgian law would be irrelevant in this regard and the Belgian legislation would have to be amended to the extent that it introduces discrimination between countries that had a given system of family allowances and those that had a different system or no system, and made the granting of the exemption subject to certain conditions " (Belgian Family Allowances, 1952, pp.33-34). 
Frans Lavdari, Extsv. Rev.; Vol. 1, Issue 1, pp: 16-29, 2021

The words "any advantage, favour, privilege, or immunity ... granted immediately and unconditionally to the similar product originating in the territories of all the contracting parties" make it clear that the most favoured nation principle is determined absolutely and universally in relation to any state, even those outside the original agreement with the aim of not creating treatment discrimination (Chandy \& Dasgupta, 2019, p.7).

\subsection{Advantages and Interference in National Legislation}

On the question of advantages, article I of the GATT of 1994 establishes that, when a nation offers an advantage to the products received by a nation, this "favour" is repeated on the same conditions with all the other nations adhering to the WTO. Consequently, the third countries, even if they do not belong to the agreement signed between two nations in terms of commercial or economic privileges, find themselves benefiting from the same without the "obligation" of a return, whether it is tax or of any other nature, of the advantages themselves. The granting of privileges could, however, have anomalous developments based on the product invested by the advantage. Still in relation to the issue of Belgian family allowances of November 1952, the AB found that the granting of the advantage given by Belgium was related only to countries that had a system similar to its own (in general, the neighbouring Scandinavian countries), and which created a condition of discrimination against other national realities that did not have the same mechanisms. The fact was thus sanctioned, and Belgium imposed the amendment of the rule as "incompatible with the provisions of Article I (and possibly with those of Article III, paragraph 2)", i.e., the MFN principle.

This was able to demonstrate how the principle would, in practice, have the power to impose itself in national legislative systems and modify any provision that is in conflict with its own.

\subsection{Exceptions}

Since its inception in 1947, the most favoured nation principle has undergone developments that have led to the identification and establishment of a series of "exceptions to the rule". These exclusivities were born over the years to respond to some needs that were requested by nations within the WTO.

The Japanese Ministry of Foreign Affairs ("MOFA") has indicated the existence of 401 "exceptions in the Annex on Article II exemptions of the General Agreement on Trade in Services", and whether the objective of the body is the creation of a free trade market between nations, the existence of such a large amount of exclusivity "is a deviation from this important principle" (MOFA, 2001) The Doha Round was the culmination of this development.

\subsection{Doha Round}

The Doha Development Round or Doha Development Agenda in Qatar in 2001 is a cycle of trade negotiations born with the aim of reducing customs barriers and increasing trade in the global market and not yet concluded. The results of what were the expectations of the meeting differed with reality. This was due to a series of problems that had roots in the system created within the WTO. While the Geneva Round of April 1947 saw 23 participating nations, during the meeting in Doha the number rose to 159 (González \& Jung, 2020; Heydon, 2020; Heydon, 2020; Shin \& Ahn, 2019; Reinert, 2021). The exponential increase in the number of sovereign nations that joined the WTO project grew in the same way that the adherence of developing nations did. This heterogeneity brought divergent interests and needs, which manifested themselves also thanks to the difficulty of concluding the negotiations, which only a "political response" could resolve (Calchamber, 2021; Lamy, 2011). This was echoed by another dilemma of the body, namely the "single commitment" rule, which established that any decision taken could not be agreed separately. Each decision had to represent an indivisible "package", a "single commitment: nothing is agreed until everything is agreed" (McQuaid, 2019; Wolfe, 2009; Pieraccini \& Novitz, 2020; Hanrahan \& Schnepf, 2006) The divergent needs, combined with the single commitment rule, made the singularities within the body stand out to the point that the work of negotiations slowed drastically, and the need to help the economies 
of developing countries turned into a cycle of concessions in contractual singularities in the matter of free trade. Bilateral or multilateral agreements of various kinds, such as PTAs, FTAs and RTAs, had their exaltation. Just think that only the latter (the PTAs) have had such an increase that in the period of 2020, 41 have been concluded and in force.

\section{The Existing Forms of Exceptions to the MFN Principle and Their Increase Over Time}

\subsection{PTA - FTA - RTA Agreements}

The exceptions referring to the MFN principle that may arise in commercial agreements may have characteristics in relation to the expression used, such as "preferential", "free" or "regional". Unlike their name, states that conclude an RTA are not "necessarily belonging to the same geographic region" (Goginava, 2019), but they can expand to include nations from multiple continents. In order to increase "freedom of trade" between nations, the formation of "a customs union or a free trade area", with the proviso that this does not create "obstacles to the trade of other contracting parties with these territories." The result of these conditions is an open legitimacy to the possibility of concluding specific agreements between nations that create confidential and privileged treatments with respect to third countries outside the agreement, creating an exception to the MFN principle. The GATT believes that particular conditions can arise. by way of exception and under the recognition of severe conditions established in Article XXIV, 5 (WTO, 1986, p.42; Turkey — Textiles, 1999): any form of obstacle to free trade within the region must be eliminated (a); tariffs towards non-contracting nations must not exceed the levels established in the pre-agreement period (b); finally, any interim agreement for the formation of the previous points (a) and (b) must contain a plan for their formation within a "reasonable time frame" (c). On the PTA agreement, this agreement can have both a bilateral and multilateral nature in which the contracting parties agree on certain common tariffs for certain products, which products must be enumerated in a list called "positive list". Examples of this kind of agreement can be:

1. United States (African Growth and Opportunity Act, effective from 18 May 2020; Trade preferences for Nepal, 13 December 2016; Former Trust Territory of the Pacific Islands, 1 September 1948).

2. The European Continent (from the analysis of the World Bank, in 2017 "Europe is the region with the largest number of signed PTAs" (Fahey, 2020) such as the Trade preferences for countries of the Western Balkans, in force since 1 December 2000).

3. The Asian continent (India-MERCOSUR Agreement ("ISLFTA") between India and Sri-Lanka since 1998 (Ministry of Commerce and Industry, 2021); Economic Cooperation Organization ("ECO”), since 1964).

This kind of agreement stimulates "investment through their commitment to a liberal market economy" (Postnikov, 2020; Lechner, 2018; Beverelli, Kurtz \& Raess, 2020), but has shortcomings. Gaps were found in the PTA agreements in relation to workers' rights and environmental rights. Some PTAs (Australia-USA, CAFTA, Morocco-USA and NAFTA) give workers the opportunity to file complaints in relation to working conditions, while others (Panama-USA and Singapore-USA) "do not guarantee this right". In some, the presence of local courts is explicit (CAFTA, Korea-USA, Morocco-USA and Peru-USA), "but not in all" (USA-Vietnam, Jordan-USA). (Lechner, 2018, p.173) The PTA agreements, in attracting FDI (Foreign Direct Investments) in some cases create social inequalities and do not produce a real improvement for workers and the environment. This is mirrored more in developing countries than in Western nations.

Finally, there are the FTAs, exchange agreements that differ from the PTAs by not having a "positive list" but rather a "negative list" of goods that should not be part of that new free market (Weiß \& Furculita, 2020, p.69; MOFCOM, 2021). However, the parties maintain their own tariff structure in relation to countries outside the agreement. Examples may be: ("NAFTA") North American Free Trade Agreement between the United States, Mexico and Canada and replaced from 1 July 2020 by the United States-MexicoCanada Agreement called "USMCA" (or "CUSMA" for Canada (Glick, 2020)); (“CAFTA-DR”) Dominican 
Frans Lavdari, Extsv. Rev.; Vol. 1, Issue 1, pp: 16-29, 2021

Republic - Central America Free Trade Agreement, March 1, 2006; ("CARICOM" or "CC") Caribbean Community, August 1, 1973.

\subsubsection{World Situation of RTA Agreements: A Brief Overview}

The analysis of the data reported by the WTO on the progress of the RTA agreements stipulated since the end of the Second World War show the following situation:

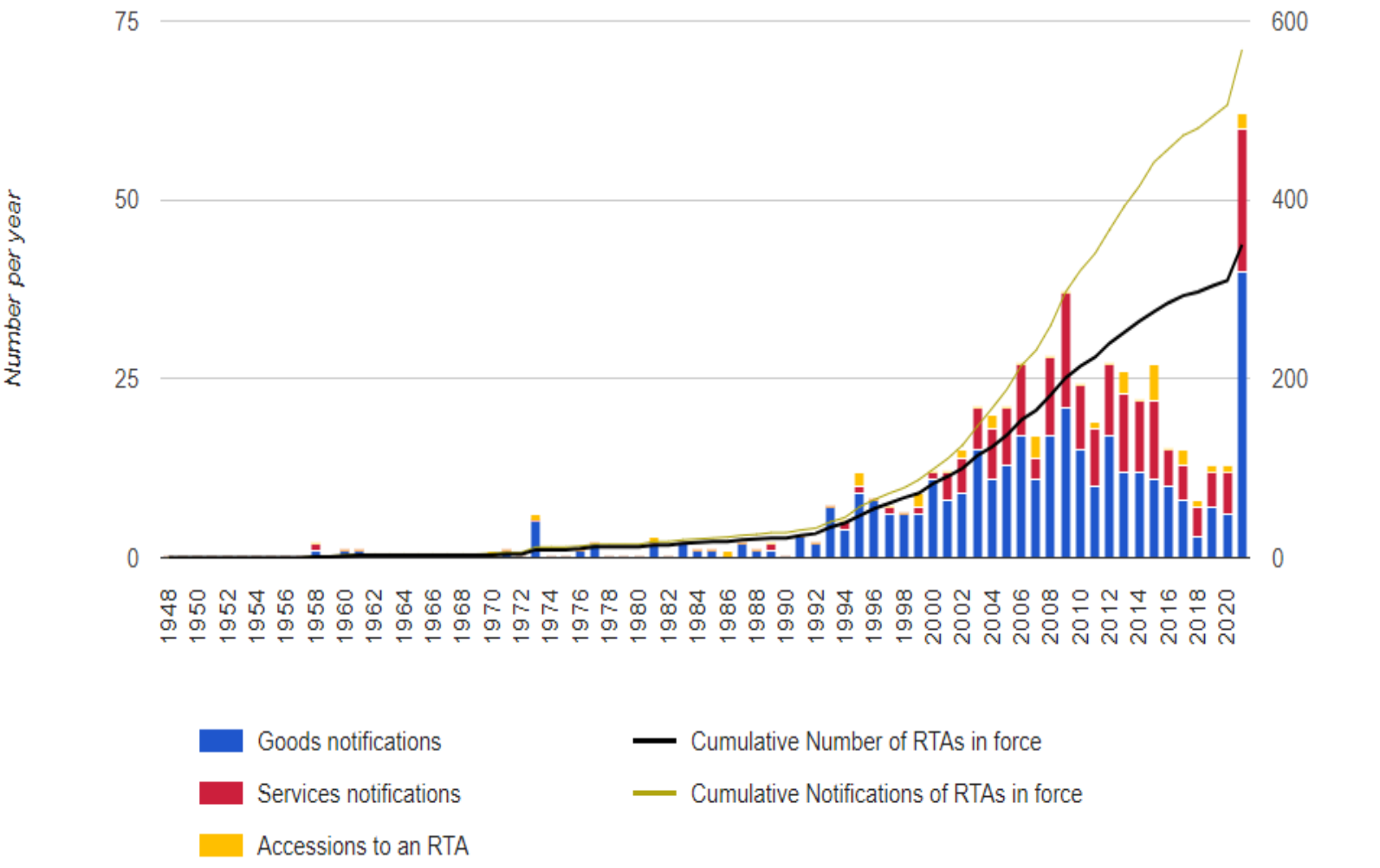

Chart 1: Source: WTO Secretariat - September 19, 2021

As reported, RTA agreements have seen a considerable increase over the years. The numbers show the transition from 31 agreements signed in the 1950/1970 period, with an average of 1.55 agreements per year, to 4659 agreements concluded in the last twenty years (2000/2020), with an average of 232.95 agreements the year. The percentage increase in the transition between the two periods reported is equal to $14,929.03 \%$, demonstrating a clear trend on the commercial level of an ever-increasing use of RTA agreements. An interesting consideration is the comparison of the period 1948/1970, the last calendar year which provided for the validity of the Bretton Woods agreements (formally lapsed on August 15, 1971 with the unilateral withdrawal by the United States of the possibility for foreign nations to convert dollars in gold) and equal to 309 compared to those concluded during the pandemic period due to COVID-19 of 2020, during which the data shows 310 RTA agreements signed between states. The result therefore reports that in 2020 alone the nations concluded a greater number of RTA trade agreements compared to the 22 years of validity of the Bretton Woods agreements.

\subsubsection{Types of RTA Contracts in 2021}

2021 reports a general situation of signed RTA agreements, as reported by the WTO, equal to 350 active agreements of which:

1. 318 carried out pursuant to Art. XXIV of the GATT

2. 188 carried out in accordance with Art. V of the GATT

3. 62 as an enabling clause 
Table 1: Products subject to RTA trade, 2021 (WTO, 2021)

\begin{tabular}{|l|l|} 
Goods & 169 \\
\hline Services & 2 \\
\hline Goods and Services & 179 \\
\hline Grand Total & $\mathbf{3 5 0}$ \\
\hline
\end{tabular}

Table 1 shows how the RTA agreements signed up to 2021 are still active today are mainly linked to the trade of products and services (179) or only products (169), and marginally to the trade of services only (2). The graph below shows the regions by concentration of established RTA agreements:

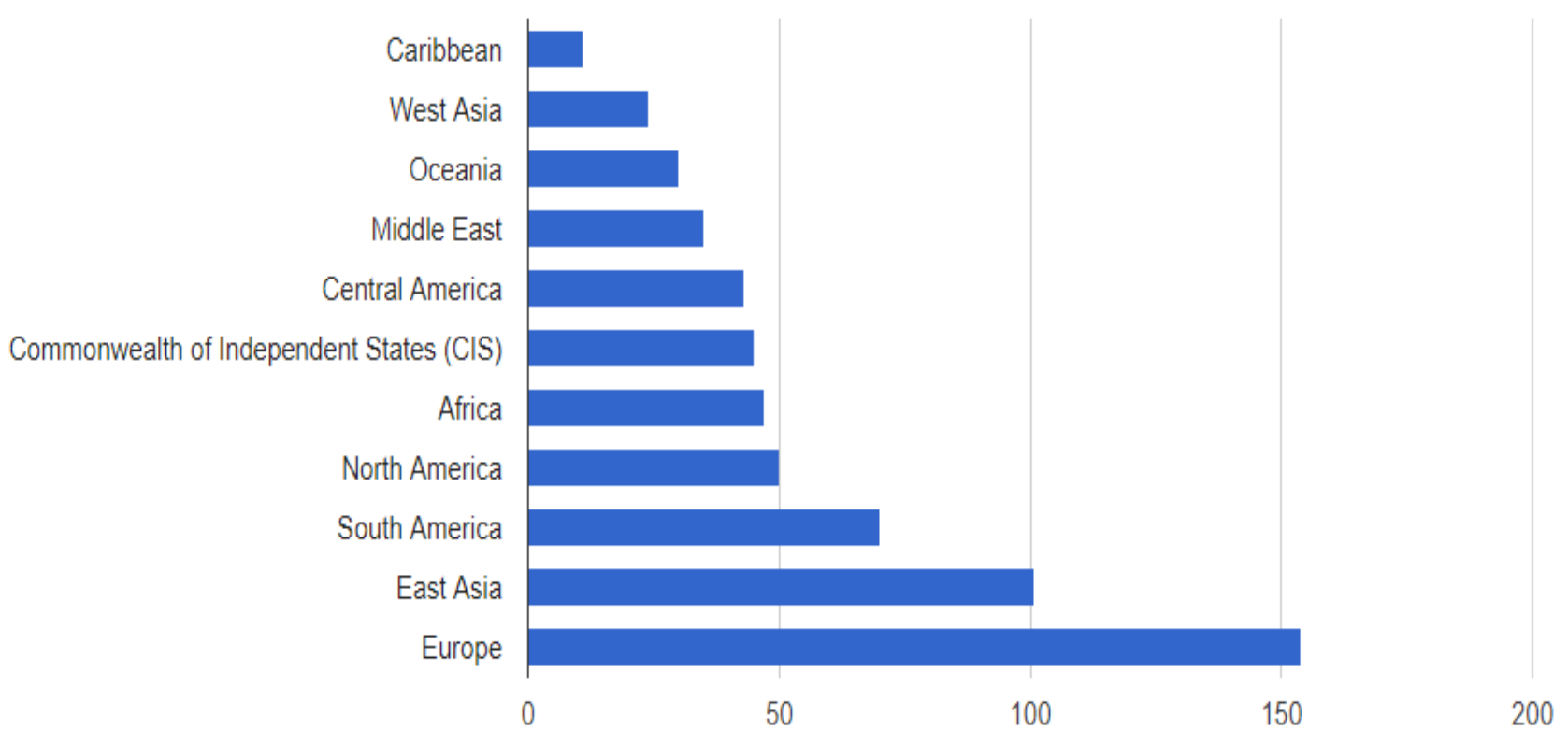

Chart 2: Source: WTO Secretariat - September 19, 2021

Among the regions with the highest number of trade agreements concluded as an exception to the MFN principle is the European Union, with 154 RTA notifications in operation, surpassing the East Asia region (101), South America (70) and North America (50), followed by Africa (47), Commonwealth of Independent States (hereinafter "CIS") (45), Central America (43), Middle East (35), Oceania (30), West Asia (24), and Caribbean (11). This, in addition to demonstrating what is established in the previous paragraph (see: PTA - FTA - RTA AGREEMENTS), demonstrates an international situation of evident abuse of the concession of exceptionality established by the Doha agreements, in particular in the last thirty years and especially in 2021, as it can be seen in Graph 3: 

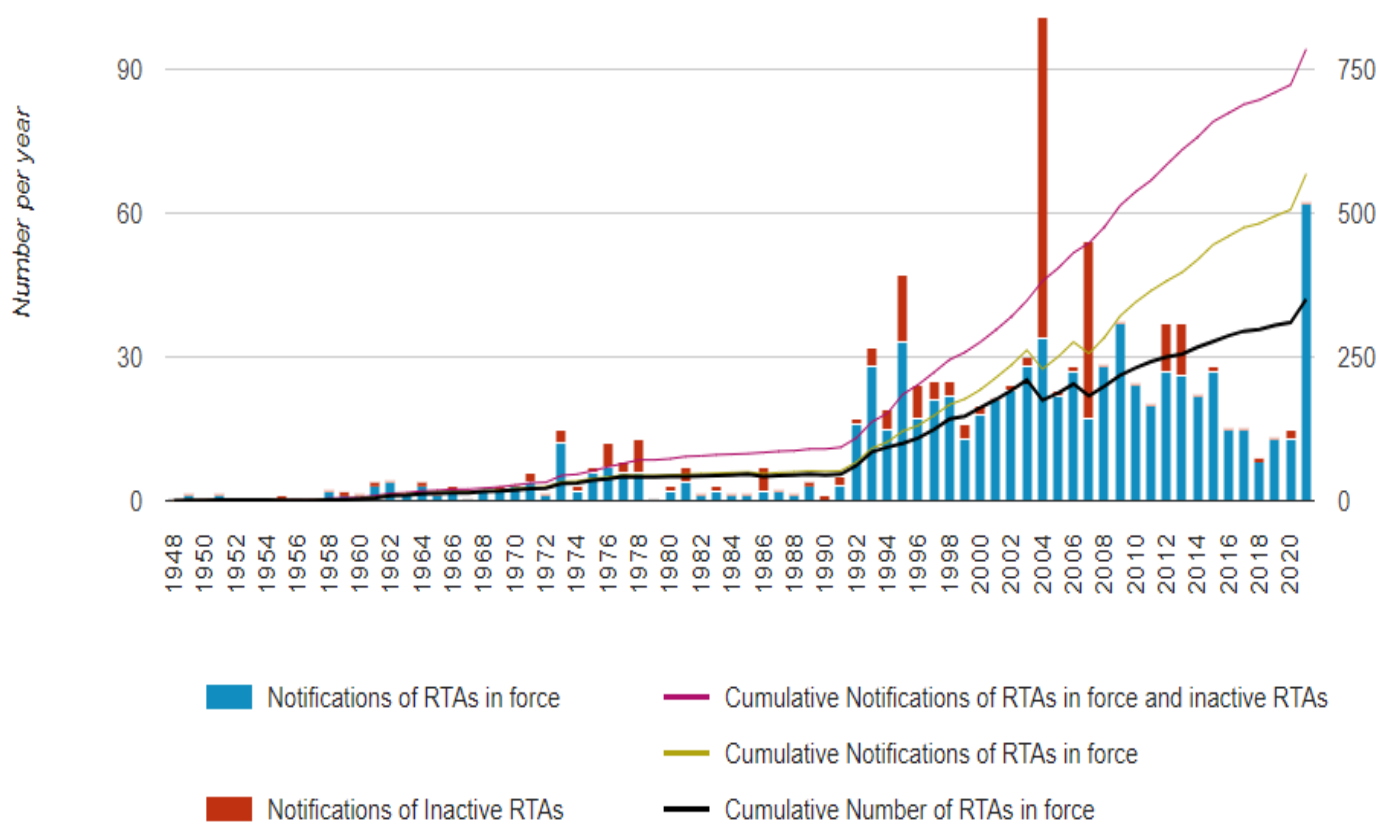

Chart 3: WTO Secretariat - September 21, 2021

In the graph above it is clear how, during the current year, exclusive free trade agreements have been undertaken between nations aimed at a greater recovery of the economies for a return to pre-pandemic situations, through an increase, in particular, of "trade agreements regional (for example RCEP and AfCFTA)", as well as a growing tension in commercial relations between developed economies. This situation is producing a transformation of international supply chains, favoring agreements with local nations, through reshoring and nearshoring trends.

\subsection{REIO and IIA}

The "Regional Economic Integration Organizations" are international agreements similar to RTAs and create an exception to Article XXIV of the GATT. The REIOs offer investors originating in one of the contracting nations the possibility of accessing on equal terms with those of citizens of another contracting country. This condition, however, generates a substantial conflict with the fees proposed by the MFN principle, as investors from non-REIO countries find themselves at a disadvantage if they want to invest in a contracting country. There is the possibility that a company decides to open a branch in a contracting country to acquire local privileges, but this is not always the case. There may be the possibility that a nonREIO member is denied the possibility of creating a branch in the REIO territory, or that "additional conditions" are subject to being able to operate in a contracting country. Examples of the latter case may be nationality (if the local company "is owned" by an individual of foreign nationality), or if the company "has no substantial commercial activities in the territory of the party under whose law it is established" (USMCA, 2020; ANZSCEP, 2020; Austria-Libya BIT, 2004; Austria-Lebanon BIT, 2002). An example is the Closer Economic Partnership Arrangement (Zang, 2020; CEPA, 2003) which establishes the criteria by which a company has specific operations in the area. The situation would worsen even more in the face of a developing country. If the country were a member of the REIO agreement then it would have the advantages with the contractors, otherwise, if the country of origin entered into an IIA ("International Investment Agreement") agreement with REIO countries, the REIO agreement would automatically limit to "non-EU" citizens of those privileges that could help their state to develop adequately. The implications of REIO arrangements can be detrimental to competitors for "host state legal and regulatory systems that are inconvenient for the investor, a low level of intellectual property protection (particularly important for 
Principle of Most Favoured Nation

investors in intellectual property intensive sectors)" or the desire to maintain a more centralized management structure" (UNCTAD, 2004, p.8).

\section{$5 \quad$ Forms of Discrimination}

\subsection{Product Classification Problems}

There is a possibility that some products will receive discriminatory treatment on the basis of the internal market in which they are produced and marketed.

For example, "a country may apply a different tariff rate to a particular variety of unroasted coffee, but if that variety and other varieties of coffee beans were considered" like products ", the differential tariff could only have an effect on imports from specific countries. " In the case of 1987 Canada vs Japan, "Japan - SPF Dimension Lumber", the $\mathrm{AB}$ determined that the classification of products is an internal prerogative of each state. In the present specific case, "if a Contracting Party has submitted a claim of similarity in relation to the tariff treatment of its goods upon import by another Contracting Party, that claim should be based on the latter's classification, i.e. say the tariff of the importing country" (Jusmundi, 2021).

\subsection{Tariffs and Administrative Costs}

As indicated by the World Bank in document 3730 (2005), "A key issue in evaluating the benefits of trade preferences to beneficiaries is the cost of obtaining the preferences" (Cipollina \& Demaria, 2020; Francois, Joseph, Hoekman \& Manchin, 2006). As previously stated, some nations enjoy advantageous commercial relationships based on particular agreements that establish, in most cases, the mutual recognition of the counterpart's companies to the agreement of privileges or benefits by local legislation through the satisfaction of the criteria imposed by the legislation of the latter, ie that of the country where the foreign company wants to market its product. In fact, Brenton \& Manchin recognize how these requirements have the task of preventing third country companies in a mutual recognition agreement of privileges from obtaining these (privileges) through "trade diversion" systems. The third country company could exploit commercial relations with one of the contracting nations to a free trade agreement in order to export its product also to the other countries adhering to the agreement without this (the company) being, therefore, actually originating from one of the member states of the free trade agreement (Bernal, 2020; Brenton \& Manchin, 2003, p.26). The recognition of the origin of a product does not appear to be particularly laborious when the production chain refers to a nation. The case is different for chains with offices in different countries, where the need to impose rules in order to establish the origin of a product are essential to be able to recognize or deny a company the right to take advantage of the facilities in other states. The system, however, generates costs for companies from third countries, in particular when companies have to deal with the administration of the rules of origin and the costs of the related documentation which I then reflect on the cost and the final product. As reported by various studies (François, Hoekman \& Manchin, 2006) the administrative measures imposed by the EEC on the countries adhering to the EFTA agreement created an increase in the cost of the products originating from the latter of about 3\% (Burfisher, 2021, p.208; Powers \& Ubee, 2020; Sun, Chand \& Sharpe, 2018). These costs are even more onerous for developing countries, where the inefficiency of bureaucracy, economic and technological backwardness create costs that affect the final product.

\section{Reasons for Exceptions to the MFN and the Consequences in Commercial Relations}

\subsection{Justifiable Reasons}

Article XX of the GATT 1994 reports a series of general cases according to which there is an exemption from the application of the MFN principle in relation to internal or external policy issues, as well as "the protection of public morals" (subparagraph (a)), "The protection of human, animal or plant life or health" (subparagraph (b)), "border regulation" (letter (d)), and "conservation of exhaustible natural resources" (letter (g)) . In addition to those present, Article XIV reports the same issue for trade in services. On the basis of the GATT 1994, each country has competent matters in the preservation of the health and 
environmental conditions of its citizens (Report of the Appellate Body, US-Gasoline, p. 30; Bacchus \& Lester, 2020; Sharma \& Behl, 2020) as well as the methods of protection of the national community (Report of the Appellate Body, Brazil - Retreaded Tires, para. 140). Further measures decreed are measures: "undertaken in compliance with the obligations deriving from intergovernmental agreements on goods" (h); "Which involve restrictions on exports of domestic materials necessary to secure essential quantities of such materials to a domestic processing industry during periods when the domestic price of such materials is kept below the world price as part of a government plan to stabilization "(i); and "essential for the acquisition or distribution of products in general or local scarcity" (j). Taking into consideration the USShrimp (1998) case, the AB stated that such cases are recognized if they do not constitute a means of "arbitrary or unjustifiable discrimination" between countries where the same conditions prevail and that it is not a form of "masking" all compliance with international trade rules (Eritja \& Fajardo, 2021, p.82). Finally, there is the question of Special and Differentiated Treatment ("SDT" or "S\&D"), recognized by the WTO as the particular and different development needs of least developed countries ("LDC") (WTO, 2021). Since it is difficult for these nations to fully assimilate the opportunities of the free market, the Marrakesh Agreement established that exceptionalities for LDC countries can arise only in the presence of: member development (through the Generalized Scheme of Preferences ("GSP") the privilege of being able to export products at more competitive prices on the market is given); (2) Provisions under which WTO members should safeguard the interests of members of developing countries (using alternative practices against LDC countries rather than accusing them of anti-dumping or countervailing); (3) Flexibility of commitments, action and use of policy instruments; (4) Transition periods; (5) Technical assistance; (6) Provisions relating to LDC members (for example, greater caution in resolving disputes) (GATS, 1994). In order to ensure the correct use of these opportunities and not their abuse, the Bali Conference in December 2013 established the "Monitoring Mechanism on Special and Differential Treatment."

\subsection{Advantages and Disadvantages Deriving from the Exceptionality}

The literature reports how the opinions regarding the growth of exceptionalities over the years are currently conflicting, and, in particular, in relation to its downgrading. Some see it as a serious danger to the international trading system. Frederick M. Abbott (2007, p.10) recalls how the system of RTA agreements is particularly advantageous for developed nations, such as the United States and the EU, which have greater negotiating power in negotiations with LDC countries, "especially the less economically powerful, they are losing the autonomous decision-making authority" (Cohn \& Hira, 2020; Onditi, 2020). This situation can give rise to a "bilateral opportunism", where some nations, thanks to their international weight, push in order to "improve their well-being at the expense of third countries excluded from the bilateral agreement". This assumption is also accepted by Gavin Goh (2006), who expresses as "Australia has recognized, RTAs can undermine the multilateral trading system where they have 'poor trade-liberalizing outcomes and trade distorting effects"' (see also Hoekman \& Tu, 2021). On the other hand, the 2001 METI report establishes that RTA agreements outside the WTO are advantageous in that they are more easily adopted (being among a few countries, they do not require lengthy negotiations) and the conditions that are adopted by the contractors are (or should be) automatically applied to third countries thanks to the MFN principle (Kimura, 2001). However, RTAs, FTAs or SDTs can, if not properly controlled, shake "the foundations of the core principle of non-discrimination, prevent member states from integrating into the international market, disrupt effective WTO negotiations and prevent continued trade expansion. international" (Hegde \& Wouters, 2020; Matthews, 2021).

\section{Conclusions}

International trade is, to date, subjected to strong global pressure from phenomena, such as globalization, which are transforming trade and, in particular, agreements between states. The effect of the inability of an international body such as the WTO to impose the MFN principle as a cornerstone in all trade agreements has meant that, since the end of the Second World War, and in particular the Doha Round agreements, free 
way to the maturation and propagation of free trade agreements (PTA, FTA, RTA, REIO) that prefer exclusive relationships with a restricted group of nations, rather than agreements that emphasize the principle of "non-discrimination" and thus equal recognition of inter-state treatments. To date, although the MFN principle has managed to undermine some provisions of national legislation (such as the Belgian family allowances) and still remain, albeit to a decreasing extent, active in international agreements, it is clear that this principle is suffering severe repercussions from part of the attitudes of nations. The personal interests of the states have set in motion a race for the "best deal", for the creation of trade agreements that create preferential corridors for some goods rather than others, and which give priority to bilateral opportunisms, although in part this has created some advantages, in terms of timing and facilities for their signing (the fewer countries conclude an agreement, the less time will be consumed in negotiations), it is equally true that regional free trade agreements can create disadvantage situations for non-adhering nations, especially LDC countries, and in particular in regional agreements establishing REIOs (Regional Economic Integration Organizations) which have the primary task of creating areas of cooperation for the development of economic activities and which can be a source of support for the economies of third countries world.

\section{Competing Interests}

The author declared that they have NO affiliations with or involvement in any organization or entity with any financial interest (such as honoraria; educational grants; participation in speakers' bureaus; membership, employment, consultancies, stock ownership, or other equity interest; and expert testimony or patentlicensing arrangements), or non-financial interest (such as personal or professional relationships, affiliations, knowledge or beliefs) in the subject matter or materials discussed in this manuscript.

\section{How to Cite this Article:}

F. Lavdari, "Principle of Most Favoured Nation: Description, Modern Evolution, and Analysis of the Exceptionality of the Principle in A Contemporary World", Extsv. Rev., vol. 1, no. 1, pp. 16-29, Dec. 2021.

\section{References}

Abbott, F. M. (2007). A new dominant trade species emerges: Is bilateralism a threat? Journal of International Economic Law, 10(3), 571583. https://doi.org/10.1093/jiel/jgm021.

Arndt, S. W. (1986). (rep.). Analysis of Conditional vs. Unconditional Most Favored Nation Status (pp. 1-54). Claremont, California (US): CMC Faculty Publications and Research.

Building a More Equitable and Inclusive Free Trade Agreement. (2020). In J. Borrows \& R. Schwartz (Eds.), Indigenous Peoples and International Trade: Building Equitable and Inclusive International Trade and Investment Agreements (pp. 131-319). Cambridge: Cambridge University Press.

Besik Goginava. (2019). Peculiarities of Modern Latin American Regionalism. Advances in Social Sciences Research Journal, 6(8), 109-118. https://doi.org/10.14738/assrj.68.6888.

Belgium - Family Allowances G/32 - BISD 1S/59 (1952).

Beverelli, C., Kurtz Jürgen, \& Raess, D. (2020). International trade, investment, and the sustainable Development goals: World trade Forum. Cambridge University Press.

Berger, S., Fengler, S., Owetschkin, D., \&amp; Sittmann, J. (2021). Cultures of transparency: Between promise and peril (1st ed.). Routledge.

Burfisher, M. (2021). Introduction to Computable General Equilibrium Models (3rd ed.). Cambridge: Cambridge University Press. doi:10.1017/9781108780063.

Bernal, R. L. (2020). Corporate versus national interest in Us trade Policy Chiquita and Caribbean Bananas. Springer International Publishing.

Brenton, P., \&amp; Manchin, M. (2003). Making eu trade agreements work: The role of rules of origin. The World Economy, 26(5), 755769. https://doi.org/10.1111/1467-9701.00545

Chandy, S. T., \&amp; Dasgupta, A. (2019). Government Procurement: A Multilateral Perspective into Goods and Services Trade. CTIL DISCUSSION PAPER SERIES.

Cebi, Pinar \& Ludema, Rodney, 2002. "The Rise and Fall of the Most-Favored-Nation Clause," Working Papers 15853, United States International Trade Commission, Office of Economics.

Canada/Japan - Tariff on Imports of Spruce, Pine, Fir (SPF) Dimension Lumber (https://jusmundi.com/en/document/decision/en-canadajapan-tariff-on-imports-of-spruce-pine-fir-spf-dimension-lumber-panel-report-wednesday-26th-april-1989 April 26, 1989).

Cottier, T., Mavroidis, P. C., \&amp; Blatter, P. (2000). Regulatory Barriers and the Principle of Non-discrimination in World Trade Law: Past, Present, and Future. University of Michigan Press.

Cohn, T. H., \&amp; Hira, A. (2021). Global political economy: Theory and practice (8th ed.). Routledge, Taylor \&amp; Francis Group.

China and Singapore held the first round of follow-up negotiations on FTA upgrade. MOFCOM. (2021, April 1). Retrieved September 21, 2021, from http://english.mofcom.gov.cn/article/newsrelease/significantnews/202104/20210403050370.shtml.

Claussen, Kathleen, Trade Administration (March 15, 2020). 107 Va. L. Rev. 845 (2021), Available at SSRN: https://ssrn.com/abstract=3602190 or http://dx.doi.org/10.2139/ssrn.3602190 
Frans Lavdari, Extsv. Rev.; Vol. 1, Issue 1, pp: 16-29, 2021

Claussen, Kathleen, Trade Administration (March 15, 2020). 107 Va. L. Rev. 845 (2021), Available at SSRN: https://ssrn.com/abstract=3602190 or http://dx.doi.org/10.2139/ssrn.3602190

Chandy, S. T., \&amp; Dasgupta, A. (2019). Government Procurement: A Multilateral Perspective into Goods and Services Trade. CTIL DISCUSSION PAPER SERIES.

Choukroune Leilla, \&amp; Nedumpara, J. J. (2021). International economic law text, cases and materials. Cambridge University Press.

Cipollina, M., \& Demaria, F. (2020). The Trade Effect of the EU's Preference Margins and Non-Tariff Barriers. Journal of Risk and Financial Management, 13(9), 203. doi:10.3390/jrfm13090203.

Deeksha Sharma \& Tushar Behl, (2020), Expanding the restricted realm of international trade law to animal welfare, Völkerrechtsblog, doi: 10.17176/20210107-183516-0.

Eugene J. Conroy, (1927). American Interpretation of the Most Favored Nation Clause, 12 Cornell L. Rev. 327.

Francois, J. F., Hoekman, B., \&amp; Manchin, M. (2006). Preference erosion and multilateral trade liberalization. SSRN Electronic Journal. https://doi.org/10.2139/ssrn.922038.

Fahey, E. (2020). Framing Convergence with the Global Legal Order: The Eu and the World (1st ed.). HART PUBLISHING.

Fajardo, Teresa \& Campins Eritja, Mar. (2021). Biological Diversity and International Law. Challenges for the Post 2020 Scenario, Springer, July 2021. 10.1007/978-3-030-72961-5.

GATS: General Agreement on Trade in Services, (1994), Marrakesh Agreement Establishing the World Trade Organization, Annex 1B, 1869 U.N.T.S. 183, 33 I.L.M.

Gavin Goh, (May 2006) Regional Trade Agreements and Australia: A National Interest Perspective, Australian APEC Study Centre, Monash University.

González, Anabel and Euijin Jung (2020) Developing Countries Can Help Restore the WTO's Dispute Settlement System. Available at: https://www.piie. com/sites/default/files/documents/pb20-1.pdf.

Glick, L. A. (2020). The United States-Mexico-Canada Agreement (usmca): Legal and business implications. Wolters Kluwer.

Grossman, G. M. (2016). The purpose of trade agreements. National Bureau of Economic Research . https://doi.org/10.3386/w22070.

Goyal, T. M. (2021). Technology Uncertainty and Incompleteness in Trade Agreements: Reflections from the Design of India's Bilateral Agreements Covering Services. Foreign Trade Review, 56(3), 322-340. https://doi.org/10.1177/0015732520981511.

Harstad, B. (2021). TRADE AND TREES. https://doi.org/https://www.sv.uio.no/econ/personer/vi//bardh/dokumenter/tt.pdf

Hegde, V., \&amp; Wouters, J. (2020). Special and Differential Treatment under the World Trade Organization: A Legal Typology. Leuven Centre for Global Governance Studies. https://doi.org/https://ghum.kuleuven.be/ggs/publications/working_papers/wp227-specialand-differential-treatment-wto-legal.pdf

Heydon, K. (2020). The political economy of international trade: Putting commerce in context. Polity Press.

Hoekman, B., \&amp; Tu, X. (2021, September). Resuscitating multilateral trade cooperation: A new ebook. VOX, CEPR Policy Portal. Retrieved September 21, 2021, from https://voxeu.org/article/resuscitating-multilateral-trade-cooperation-priority-china-eucooperation.

Hoekman, B., \&amp; Tu, X. (2021, July 12). Resuscitating multilateral trade cooperation: A new ebook. VOX, CEPR Policy Portal. Retrieved September 21, 2021, from https://voxeu.org/article/resuscitating-multilateral-trade-cooperation-priority-china-eu-cooperation.

Hanrahan, C. E. \& Schnepf, R. (2006). Wto Doha round the Agricultural negotiations. Congressional Research Service, Library of Congress. James Bacchus, Simon Lester, 'The Rule of Precedent and the Role of the Appellate Body', (2020), 54, Journal of World Trade, Issue 2, pp. 183-198, https://kluwerlawonline.com/journalarticle/Journal+of+World+Trade/54.2/TRAD2020008.

Kimura, F. (2001). The Task of External Economic Policies in the 21St Century. - Sense Of Emergency Found in The White Paper on International Trade 2001. Journal of Japanese Trade \&amp; Industry, 32-35.

Kregel, J. (2021). Another Bretton Woods Reform Moment: Let Us Look Seriously at the Clearing Union (Ser. 154). Levy Economics Institute of Bard College.

Lamy, P. (2011). MINISTERIAL CONFERENCE . In Eighth WTO Ministerial Conference. Geneva, Switzerland; WTO. Retrieved from https://www.wto.org/english/thewto_e/minist_e/min11_e/min11_5_e.pdf.

Lechner, L. (2018). Good for some, bad for OTHERS: US investors AND Non-trade issues in preferential trade agreements. The Review of International Organizations, 13(2), 163-187. https://doi.org/10.1007/s11558-018-9299-2.

Laird, S., \& Cordoba, S. F. de. (2006). Coping with trade reforms A developing-country perspective on the Wto industrial Tariff Negotiations. Palgrave Macmillan.

Labinski, N. (2017). A Transitional Moment: William Mckinley'S Foreign Policy Rhetoric And America'S Outward Turn (thesis). University of Kansas, Lawrence.

Müller, H., \&amp; Boczek, K. (2020). A Fading Institution 25 years of the World Trade Organization: the WTO through the media looking glass. Bertelsmann Stiftung.

Matthews, Alan. (2021). Is it possible to promote an agricultural agenda in the WTO? in Hoekman, B., T. Xinquan and Dong, W. (eds), Rebooting Multilateral Trade Cooperation: Perspectives from China and Europe, London, CEPR Press, 2021.

Morley, J. (1905). The life of Richard Cobden: With a bibliography. Fisher Unwin.

MOFA. (2001, May). MFN exemption: Analysis and proposal. MOFA. Retrieved May 4, 2021, from https://www.mofa.go.jp/policy/economy/wto/mfn0105.html.

McQuaid, S. D. (2019). "Nothing is agreed until everything is agreed": institutionalizing radical disagreement and dealing with the past in Northern Ireland. I I. Bramsen, P. Poder, \& O. Wæver (red.), Resolving international conflict: dynamics of escalation and continuation (s. 149-164). Routledge. Studies in Peace and Conflict Resolution.

Miller, D. H. (1931). Treaties and other international acts of the United States of America / edited by Hunter Miller. United States Government Printing Office.

Ministry of Foreign Affairs and Trade. (2001). Agreement between New Zealand and Singapore on a closer Economic Partnership: Singapore, 14 November 2000 (entered into force for New zealand, 1 January 2001).

OECD (2008), International Investment Law: Understanding Concepts and Tracking Innovations: A Companion Volume to International Investment Perspectives, OECD Publishing, Paris, https://doi.org/10.1787/9789264042032-en. 
Onditi, F. (2021). Dominatarian Theory of Regional Integration. Insight on Africa, 13(1), 76-94. https://doi.org/10.1177/0975087820971451. P.R.C.-H.K., (2003), Mainland and Hong Kong Closer Economic Partnership Arrangement (CEPA).

Palen, M.-W. (2021). Pandemic protectionism: Revisiting the 1918 "Spanish" flu in the era of covid-19. Diplomatic History, 45(3), 571-579. https://doi.org/10.1093/dh/dhab014.

Postnikov, E. (2020). Social standards in Eu and Us trade agreements. Routledge.

Powers, W., \& Ubee, R. (2020). A COMPREHENSIVE COMPARISON OF RULES OF ORIGIN IN U.S. TRADE AGREEMENTS.

Pieraccini, M. \& Novitz, T. (2020). Legal perspectives on sustainability. Bristol University Press.

Press Release, Ambassador Rob Portman, U.S. Trade Representative, Statement on Signing of U.S.-Central American-Dominican Republic Free Trade Agreement (Aug. 2, at http://www.ustr.gov/Document_Library/Press_Releases/2005/August/Statement_of_USTR_Rob_Portman_on_Signing_of_USCentral_American-Dominican_Republic_Free_Trade_Agreement_printer.html.

Reinert, K. A. (2021). An introduction to international economics new perspectives on the world economy. Cambridge University Press.

Ridgway, W. H. (2011). A century of LAWMAKING for a New Nation: U.S. Congressional documents and DEBATES, 1774-1875. Journal of American History, 97(4), 1196-1197. https://doi.org/10.1093/jahist/jaq046.

SHIN, W., \& AHN, D. (2019). Trade Gains from Legal Rulings in the WTO Dispute Settlement System. World Trade Review, $18(1)$, 1-31. doi:10.1017/S1474745617000544.

Seymour J. Rubin, (1981) Most-Favored-Nation Treatment and the Multilateral Trade Negotiations: a Quiet Revolution, 6 Md. J. Int'l L. 221. Available at: http://digitalcommons.law.umaryland.edu/mjil/vol6/iss2/7

Sun, Tianyu and Chand, Satish and Sharpe, Keiran (2018): Effect of Aging on Housing Prices: A Perspective from an Overlapping Generation Model.

SHARMIN, T. A. N. J. I. N. A. (2021). Application of most-favoured-nation clauses by investor-state arbitral tribunals: Implications... for the developing countries. SPRINGER.

Sun, T., Chand, S., \& Sharpe, K. (2018). Effect of Aging on Housing Prices: A Perspective from an Overlapping Generation Model.

Takekazu Iwamoto, (1995) Keynes Plan for an International Clearing Union Reconsidered, Kyoto University Economic Review, 65, n. 2, pp. 27-42.

The role of GATT in relation to trade and development (2021) <https://docs.wto.org/gattdocs/q/GG/L2799/2171.PDF> accessed 21 May 2021.

Tasca, H. J. (1938). The reciprocal trade policy of the United states: a study in Trade Philosophy. Univ. of Pennsylvania Pr. usw.

Turkey - Restrictions on Imports of Textile and Clothing Products (May 31, 1999).

Taussig, F. W. (1889). The tariff history of the United states: A series of essays. G.P. Putnam's Sons.

UN. (1975). Yearbook of the international Law Commission (2nd ed.).

United States - standards for reformulated and conventional gasoline. (1996). Panel Reports. https://doi.org/10.30875/cef17d2e-en.

UNCTAD. (2004). The Reio exception in mfn Treatment Clauses. United Nations.

UNCTAD (Ed.). (1948). Final act and related documents. UNITED NATIONS CONFERENCE ON TRADE AND EMPLOYMENT.

United States - Import Prohibition of Certain Shrimp and Shrimp Products (WT/DS58/AB/R October 12, 1998).

Vadi, V. (2014). " Nature, Culture and Sustainable Development in International Trade Law". In Environmental Protection and Sustainable Development from Rio to Rio+20. Leiden, The Netherlands: Brill | Nijhoff. doi: https://doi.org/10.1163/9789004282919_021.

Weiß, W., \&amp; Furculita, C. (2020). Global politics and Eu trade Policy facing the challenges to a Multilateral Approach. Springer International Publishing.

Wolfe, R. (2009). The WTO SINGLE undertaking as Negotiating technique AND Constitutive Metaphor. Journal of International Economic Law, 12(4), 835-858. https://doi.org/10.1093/jiel/jgp038.

Welcome to department of commerce, G. of I. (2014). India-MERCOSUR preferential TRADE Agreenent (PTA) NEGOTIATIONS. Mcommerce. Retrieved May 4, 2021, from https://commerce.gov.in/international-trade-trade-agreements-indias-currentengagements-in-rtas/india-mercosur-preferential-trade-agreenent-pta-negotiations/.

WTO (1986) General Agreement on Tariffs and Trade.

WTO. (2003). Dispute settlement. United Nations.

WTO. (2021). Special And Differential Treatment Provisions In Wto Agreements And Decisions. WTO Committee on Trade and Development.

WTO (2021), Annual Report 2021, WTO, Geneva, https://doi.org/10.30875/b75dea7e-en.

ZHANG, Yang. "CHAPTER 5: CEPA and Mainland-Hong Kong's Economic Relations". In EAI Series on East Asia, 85-101. WORLD SCIENTIFIC, 2020. http://dx.doi.org/10.1142/9789811200328_0006.

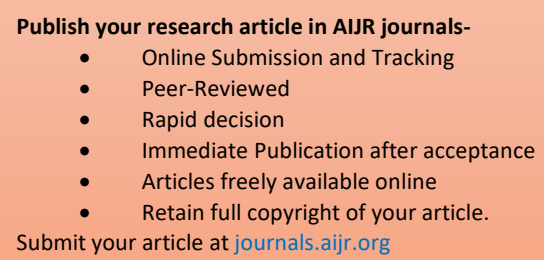

Publish your books with AIJR publisher-

- Publish with ISBN and DOI.

- Publish Thesis/Dissertation as Monograph.

- Publish Book Monograph.

- Publish Edited Volume/ Book

- Publish Conference Proceedings

- Retain full copyright of your books

Submit your manuscript at books.aijr.org 